NOTICE: This is the author's version of a work that was accepted for publication in Minerals Engineering. Changes resulting from the publishing process, such as peer review, editing, corrections, structural formatting, and other quality control mechanisms may not be reflected in this document. Changes may have been made to this work since it was submitted for publication. A definitive version was subsequently published in Minerals Engineering, Vol. 20 (2014). doi: 10.1016/j.mineng.2006.12.003 


\title{
FINE GRINDING IN A HORIZONTAL BALL MILL
}

\author{
T. PARTYKA ${ }^{\dagger}$ and D. YAN ${ }^{\dagger}$ \\ $†$ WA School of Mines, Curtin University, LB 22 Kalgoorlie, WA 6433, Australia
}

Keywords: Comminution, Grinding

\begin{abstract}
The fine grinding of ores is increasing due to the depletion of coarse grained, easily processed ore bodies and the increased need to process disseminated, fine grained deposits. The main reason ball mills are not utilised for fine grinding is the perceived poor energy efficiency generally experienced when grinding to fine sizes. However there is a trend towards ball mill grinding for product sizes below the traditional ball mill cut-off of $45 \mu \mathrm{m}$.

The effect of ball size on the feed and product size distributions in a fine grinding situation was studied. The grinding tests identified a number of trends for fine grinding, including:

- $\quad$ Efficient grind curves forming the same shape as for traditional grinding (exponential decay),

- The results supporting the claim that fine material is best ground with small media and coarse material with larger media,

- The smallest charge was most efficient at treating the finer feeds,

- The smaller charges were very ineffective and inefficient for grinding of the coarser feeds,

- $\quad$ Efficient grind was undertaken by smaller charges than that recommended by Bond's ball sizing formula, and

- $\quad$ Operating work index analysis confirming the results of the $\mathrm{P}_{80}$-energy analysis
\end{abstract}

\section{Introduction}

As coarse grained, easily processed ore bodies are depleted, more disseminated, fine-grained ores are being treated. Adequate liberation of valuable components within a fine-grained ore is often only achieved once the particle size of the ore has been reduced to levels below the traditional ball mill cut-off of $45 \mu \mathrm{m}$.

To aid in the economic liberation of fine-grained minerals, fine grinding was identified in the early 1990's as a suitable process for the minerals industry. Liberation options include a coarse primary grind and produce a concentrate and middling with re-grinding of the concentrate and/or the middling to finer sizes to achieve final liberation or fine grinding of the whole ore. In recent years, the popularity of vertical and horizontal stirred mills, such as the Svedala Vertimill (Jankovic and Morrell, 2000) and the IsaMill (Reese, 2000), has increased significantly with these mills now being used for many ultra-fine grinding applications. These mills have been shown to overcome the disadvantages of trying to achieve fine grind sizes in tumbling mills, whilst being energy efficient. In this paper, fine grinding is used to describe the size reduction to an $80 \%$ passing size between 45 and 25 microns and ultra-fine grinding is considered for sizes below 25 microns.

Fine grinding in traditional ball mills has not been utilised in the past due to the following perceived disadvantages:

- The mill speed has to be lower than the centrifugal speed of the mill otherwise the whole charge will rotate with the mill body and no grinding will occur. This speed limit fixes the maximum electrical power the mill can draw;

- The size of the inactive zone increases as the ball size becomes smaller;

- A large part of the volume of the mill has to be kept empty to allow the mill charge to tumble (Gao and Weller, 1994).

The main reason, however, is the poor energy efficiency generally experienced by horizontal tumbling mills when grinding to fine sizes (Zheng et al, 1994; Yan et al, 1995).

While the above problems may be characteristic of horizontal mills, recent research and test-work by fine grinding media manufacturers, and the current use of the technology, has shown that these 
disadvantages can be overcome and that it is possible to achieve efficient size reduction in horizontal ball mills. It has been shown that either power consumption can be reduced or through-put increased for a nominated fine grind size, without the need to invest in new equipment if a horizontal ball mill is already in use.

While stirred media mills have shown to be more energy efficient than ball mills for ultra-fine grinding $(<25 \mu \mathrm{m}$ product size), they still have limitations. One such limitation is the size of the mills available and hence the low throughput achievable (currently less than $100 \mathrm{tph}$ ). Secondly, ultra-fine grinding still consumes large amounts of energy $(100 \mathrm{kWh} / \mathrm{t}$ or more). It is well known that large size and therefore high throughputs are possible in ball mills. From this it can be argued that the costs associated with purchasing, installing and operating one ball mill will be less than those for purchasing, installing and operating multiple stirred mills for the same throughput.

Ball mills have been used for particle size reduction for many decades and a great wealth of information about their operation exists. Being a well known technology and with much research carried out in the past into grinding in a ball mill, further studies into fine grinding in a ball mill should result in confirmation of the viability of using ball mills for fine grinding situations.

At grind sizes below 20 to $30 \mu \mathrm{m}$, ball mills become inefficient (Yan et al, 1995) and steel media contamination is a problem. Iron contaminates the ground product and starts to alter the chemistry of the next unit operation - be it leaching or flotation (Pease et al, 2004). Because of this, grinding below $25 \mu \mathrm{m}$ in a horizontal ball mill is not practicable.

The aim of this experimental work was to study the effect of ball size on the feed and product size distributions in a ball mill fine grinding situation.

\section{Mill Feed/Ball Size Distribution}

It is well known from Bond's comminution theories that the feed top size determines the largest ball size required for particle breakage. Bond (1961), in his comminution theories stated, "the general principle of selection should be that the proper size of make-up grinding media is the size which will just break the largest feed particles." This is best determined for each specific situation by lengthy comparative testing. Bond found that for a given feed size the largest size ball required could be determined using the following equation:

$$
\mathrm{B}=25.4 \sqrt{\frac{\mathrm{F}}{\mathrm{K}}} \sqrt[3]{\frac{\mathrm{SGx} \mathrm{W}}{(\% \mathrm{Cs}) \sqrt{3.281 \mathrm{D}}}}
$$

where:

$$
\begin{aligned}
& \mathrm{B}=\text { ball diameter }(\mathrm{mm}), \\
& \mathrm{F}=80 \% \text { passing size of the feed }(\mu \mathrm{m}), \\
& \mathrm{K}=\text { an empirical constant }=350 \text { for wet grinding, } \\
& \mathrm{SG}=335 \text { for dry grinding, } \\
& \mathrm{Wi}=\text { specific gravity of the material being ground, } \\
& \% \mathrm{Cs}=\text { fraction of the critical speed, and } \\
& \mathrm{D}=\text { diameter of the mill inside liners }(\mathrm{m}) .
\end{aligned}
$$

Equation (1) demonstrates that larger balls are required to break larger particles. If the feed to a fine grinding mill contains large particles then large balls will be required. However, small balls will also be required to produce the desired product fineness. Hence, if the feed size distribution is broad, the ball size distribution will also need to be broad. This will result in inefficiencies in the mill and more difficulty in obtaining the grind fineness required. To avoid this, a narrow feed size distribution should be maintained, so that a narrow ball size distribution is required and also so that few large size balls are necessary.

There are numerous sites world-wide using ball mills for fine grinding applications. Table 1 benchmarks some of these operations and provides details on the factors which affect the efficiency of fine grinding. 


\section{Experimental Program}

The experimental regime consisted of 16 grinding tests (plus control repeats) and a Bond Work Index test on a gold ore sample. The 16 tests are made up of combinations of four different feed sizes and four different ball size distributions as detailed in Table 2. The ball charge in each test maintained the Bond ball charge mass of $20 \mathrm{~kg}$.

Table 1.

Some Current Sites and Details of Fine Grinding in Ball Mills (concentrate re-grind)

\begin{tabular}{|c|c|c|c|c|c|}
\hline \multirow{2}{*}{ Site, Company } & \multirow{2}{*}{ Application } & \multicolumn{2}{|c|}{$\begin{array}{c}\text { Mill } \\
\text { Dimensions }\end{array}$} & \multicolumn{2}{|c|}{ Media } \\
\hline & & $\begin{array}{l}\text { Dia. } \\
\text { (m) }\end{array}$ & $\begin{array}{l}\text { Length } \\
\text { (m) }\end{array}$ & Type & $\begin{array}{c}\text { Size } \\
(\mathrm{mm})\end{array}$ \\
\hline Pajingo Gold Mine, Newmont & $\begin{array}{l}\text { Gold (secondary mill) } \\
90 \mathrm{tph}, 200 \rightarrow 38 \mu \mathrm{m}\end{array}$ & 3.66 & 4.18 & High $\mathrm{Cr}$ & 25 \\
\hline $\begin{array}{l}\text { Germano Iron ore } \\
\text { Concentrator -Samarco, } \\
\text { CVRD }\end{array}$ & $\begin{array}{l}\text { Iron ore } \\
340 \mathrm{tph} \\
120 \rightarrow 32 \mu \mathrm{m}\end{array}$ & 5.18 & 10.36 & $\begin{array}{l}\text { High } \mathrm{Cr} \\
\text { balls } \\
\text { Cylpebs }\end{array}$ & $20-22$ \\
\hline $\begin{array}{l}\text { Savage River, Savage River } \\
\text { Mines }\end{array}$ & $\begin{array}{l}\text { Iron ore } \\
140 \mathrm{tph}, 140 \rightarrow 43 \mu \mathrm{m}\end{array}$ & 3.90 & 8.80 & $\begin{array}{l}\text { High } \mathrm{Cr} \\
\text { balls }\end{array}$ & $25-70$ \\
\hline Macraes, Oceanagold Ltd & $\rightarrow 20 \mu \mathrm{m}$ & 3.00 & 8.20 & Balls & 15 \\
\hline $\begin{array}{l}\text { Pena Colorada, Consorcio } \\
\text { Minero Benito Juarez }\end{array}$ & $\begin{array}{l}\text { Iron ore } \\
430 \mathrm{tph}, 125 \rightarrow 38 \mu \mathrm{m}\end{array}$ & 5.00 & 10.67 & $\begin{array}{l}30 \% \\
\text { Millpeb } \\
70 \% \text { ball } \\
\end{array}$ & $\begin{array}{c}4-8 \\
\text { (millpebs) } \\
25 \text { (balls) } \\
\end{array}$ \\
\hline $\begin{array}{l}\text { Beaconsfield, Allstate } \\
\text { Exploration }\end{array}$ & $\begin{array}{l}\text { Sulphide conc. regrind mill } \\
2.5 \mathrm{tph}, \rightarrow 20 \mu \mathrm{m}\end{array}$ & 1.83 & 2.44 & Cylpebs & $22 \times 22$ \\
\hline $\begin{array}{l}\text { Tritton Copper, Tritton } \\
\text { Copper Ltd }\end{array}$ & $\begin{array}{l}\mathrm{Cu} \text { float product, regrind mill } \\
18 \mathrm{tph}, 45 \rightarrow 30 \mu \mathrm{m}\end{array}$ & 2.00 & 3.40 & Balls & 25 \\
\hline $\begin{array}{l}\text { Brunswick Mining, Noranda } \\
\text { Mining \& Exploration }\end{array}$ & $\begin{array}{l}\mathrm{Cu} / \mathrm{Pb} / \mathrm{Zn} \text { Conc. regrind mill } \\
25 \mathrm{tph}, 30 \rightarrow 25 \mu \mathrm{m}\end{array}$ & $\begin{array}{l}3.2 \\
\text { OD }\end{array}$ & $4 \mathrm{OD}$ & $\begin{array}{l}\text { Steel } \\
\text { slugs }\end{array}$ & 19 \\
\hline $\begin{array}{l}\text { Porgera Gold Mine, Placer } \\
\text { Dome }\end{array}$ & $\begin{array}{l}\text { Pyrite concentrate } \\
80-130 \text { tph, } 106 \rightarrow 30 \mu \mathrm{m}\end{array}$ & $\begin{array}{l}3.05 \\
3.05 \\
3.05 \\
\end{array}$ & $\begin{array}{l}4.27 \\
5.40 \\
4.27\end{array}$ & Balls & 30 \\
\hline $\begin{array}{l}\text { Carol Lake Operation, Iron } \\
\text { Ore Company of Canada }\end{array}$ & $\begin{array}{l}\text { Iron ore, regrind mill } \\
\mathrm{P}_{90}=+75 \mu \mathrm{m} \rightarrow \mathrm{P}_{65}=44 \mu \mathrm{m}\end{array}$ & $\begin{array}{l}4.11 \\
4.42 \\
\end{array}$ & $\begin{array}{l}8.53 \\
9.75 \\
\end{array}$ & & \\
\hline
\end{tabular}

Table 2.

Experimental Matrix of Feed sizes F1-F4 and Ball Charges C1-C4.

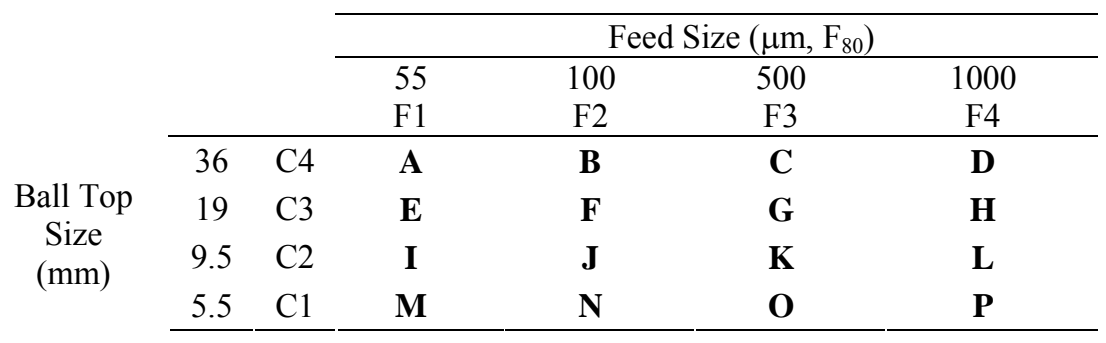

\subsection{Materials}

The ore used for these tests was a typical quartz andesite rock. The ore had an initial size of approximately minus $15 \mathrm{~mm}$. It was reduced to the feed sizes in Table 2 by a combination of cone crushing, roll crushing, rod and ball milling. Two coarser feeds and two fine feeds were obtained. 
The grinding charge for the tests consisted of a constant mass of various sized steel balls, as detailed in Table 3. The percent of each ball size to be used for each charge was determined by grinding ball manufacturer, Donhad Australia Pty Ltd (Wardell-Johnson, 2006). The charges maintained a similar ball size distribution to the Bond Ball charge but with varying top ball size.

Table 3.

Ball Charges for Test work

\begin{tabular}{cccc}
\hline Charge & $\begin{array}{c}\text { Ball size } \\
\text { (mm) }\end{array}$ & $\begin{array}{c}\text { \% of } \\
\text { size }\end{array}$ & $\begin{array}{c}\text { Mass of size } \\
\text { (kg) }\end{array}$ \\
\hline C1 & 5.5 & 38 & 7.91 \\
& 3.2 & 44 & 9.16 \\
& 2.4 & 18 & 3.75 \\
\cline { 2 - 4 } & total & 100 & 20.82 \\
\cline { 2 - 4 } & & & \\
\end{tabular}

\begin{tabular}{cccc}
\hline Charge & $\begin{array}{c}\text { Ball size } \\
\text { (mm) }\end{array}$ & $\begin{array}{c}\text { \% of } \\
\text { size }\end{array}$ & $\begin{array}{c}\text { Mass of size } \\
\text { (kg) }\end{array}$ \\
\hline \multirow{2}{*}{ C2 } & 9.5 & 38 & 7.91 \\
& 6.4 & 44 & 9.16 \\
& 3.2 & 18 & 3.75 \\
\cline { 2 - 4 } & total & 100 & 20.82 \\
\cline { 2 - 4 } & & & \\
\end{tabular}

\begin{tabular}{cccc} 
C3 & 19 & 32 & 6.67 \\
& 15 & 36 & 7.49 \\
& 9.5 & 22 & 4.58 \\
& 5.5 & 10 & 2.08 \\
\hline & total & 100 & 20.82 \\
\hline
\end{tabular}

\begin{tabular}{cccc} 
C4 & 36 & 32 & 6.68 \\
& 27 & 36 & 7.55 \\
& 19 & 22 & 4.57 \\
& 10 & 10 & 2.08 \\
\hline total & 100 & 20.88 \\
\hline
\end{tabular}

The mill used for the tests was a standard Bond Ball Mill, with an internal diameter and length of 30.5 $\mathrm{cm}$.

For all of the tests, the mill was operated at 70 revolutions per minute (RPM) with a ball loading of $20 \%$ (by volume). The amount of ore used for each test was the mass equivalent to $700 \mathrm{~mL}(1.15 \mathrm{~kg})$. These parameters were the same as those used by Bond (1961) and adopted by Levin (1984) in their grinding test work.

\subsection{Grinding Tests}

The method used for the 16 grinding tests (plus four repeats) was based on that of the Levin Test (Levin, 1984) for determining the grindability of fine materials. In the Levin Test a mass of fine material is ground in a Bond laboratory ball mill for various times (e.g. 5, 10, $15 \mathrm{~min}$ ) and the particle size distribution determined for each product. From each of the size distributions the percentage of material below $75 \mu \mathrm{m}$ is determined and plotted against grind time. From this graph the grinding time required for a given percentage of material to be ground smaller than $75 \mu \mathrm{m}$ can be determined. This time is then used to determine the energy that will be consumed to produce the desired product according to Equation 2.

Energy consumed $=\frac{\mathrm{t}}{\mathrm{m}} \times 10^{6} \times \mathrm{E}$

where:

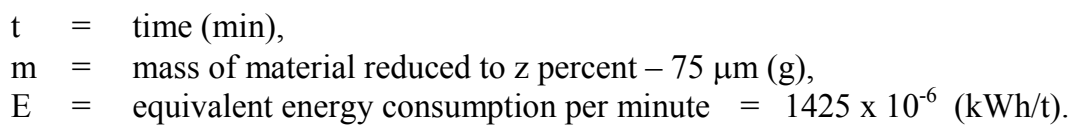

In the grinding tests for this work, each sample was ground for five minutes, sized and ground for another five minutes. This was continued for a total grind time of twenty minutes. This technique was repeated for each feed-ball size combination and the duplicates.

For the $1000 \mu \mathrm{m}$ and $500 \mu \mathrm{m}$ feeds (F4 and F3, Table 2) the size distributions were determined through sieving, while laser sizing was used for the other feeds. As the grinding results were compared according to the feed size and aimed to identify trends, not quantify the magnitude of reduction, it was not necessary to ensure the two sizing methods produced comparable results. Small samples, representing approximately 
$1 \%$ of the total mass, were removed from various positions within the mill and stored for laser sizing. For sieve sizing, larger samples were taken in the same manner, sieve sized and returned to the mill for further grinding. A check of the accuracy of the sampling technique was made by comparing the size distribution from the whole mill product, with that of the sample. The difference between the size distributions was minimal and within the variation expected from multiple sizings of the same sample, hence the sampling technique was deemed acceptable.

\section{Results and Discussion}

The Bond Ball Mill Work Index $\left(\mathrm{W}_{\mathrm{i}}\right)$ was measured as $24 \mathrm{kWh} / \mathrm{t}$ at a test screen size of $106 \mu \mathrm{m}$.

The feed top size determines the largest ball size required for particle breakage. Bond found that for a given feed size the largest size ball required could be estimated using Equation 1. According to this equation, and the mill conditions in Table 3, the top ball size for the 55, 100, 500 and $1000 \mu \mathrm{m}$ feeds are 10, 14,30 and $43 \mathrm{~mm}$ respectively. As the operating work index $\left(\mathrm{W}_{\mathrm{io}}\right)$ for each of the feeds was not known before the grinding tests, the Bond Work Index was used in the calculations. The operating work index would have been higher than $\mathrm{W}_{\mathrm{i}}$ due to the fine grinding occurring. This would result in the estimated top ball sizes being higher than those estimated by the equation. The sizes predicted, are similar to the top sizes used for the four ball charges, hence the accuracy of Equation 1 to predict the best top size was determined.

Table 4.

Data used to estimate the top ball size

\begin{tabular}{cc}
$\mathrm{K}$ & 335 \\
$\mathrm{SG}$ & 2.7 \\
$\mathrm{~W}_{\mathrm{i}}$ & $24 \mathrm{kWh} / \mathrm{t}$ \\
$\% \mathrm{Cs}$ & $70 \%$ \\
$\mathrm{D}$ & $0.305 \mathrm{~m}$ \\
\hline
\end{tabular}

\subsection{F1 (55 $\mu \mathrm{m})$ Feed Grinding Tests}

Figure 1 shows the results for the grinding tests carried out on the finest feed. The energy reported on the $\mathrm{x}$-axis is that calculated from Equation 2. Figure 1 shows that all the charges are suitable for fine grinding as they are all able to grind below $45 \mu \mathrm{m}$ and have the same shape as for traditional ball mill grinding. The smallest charge is the most efficient as it achieved a finer grind for less energy consumption than the other charges. To achieve a grind of $30 \mu \mathrm{m}$, an energy saving of approximately $27 \%$ was observed by using the smallest charge over the next larger charge.

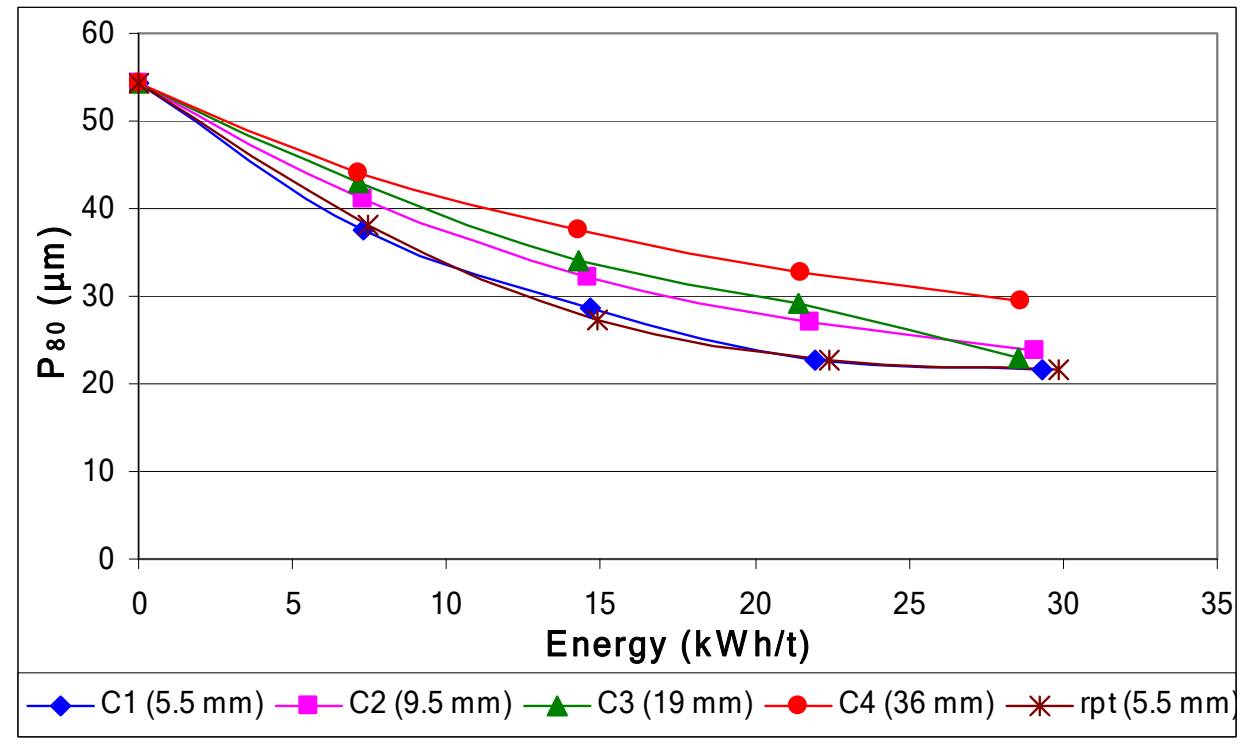


Fig. 1: $\mathrm{P}_{80}$ verses Energy for the $55 \mu \mathrm{m}$ feed (F1)

From Bond's ball sizing formula, the recommended top ball size for this feed was $10 \mathrm{~mm}$. This is the top ball size of Charge 2 (C2), the pink curve ( $)$ in Figure 1, which should have produced the best grind. However, a finer grind was achieved using Charge 1 (C1), indicating that Bond's equation may not be entirely accurate for small mills and fine grinding.

\subsection{F2 (100 $\mu \mathrm{m})$ Feed Grinding Tests}

The results represented in Figure 2 represent the grinding tests on the $100 \mu \mathrm{m}$ feed. As with the previous results, all charges are suitable for fine grinding and the smallest charge is also the most efficient. With this feed to achieve a $30 \mu \mathrm{m}$ grind, an energy saving of approximately $68 \%$ could be achieved by using the smallest charge over the next larger.

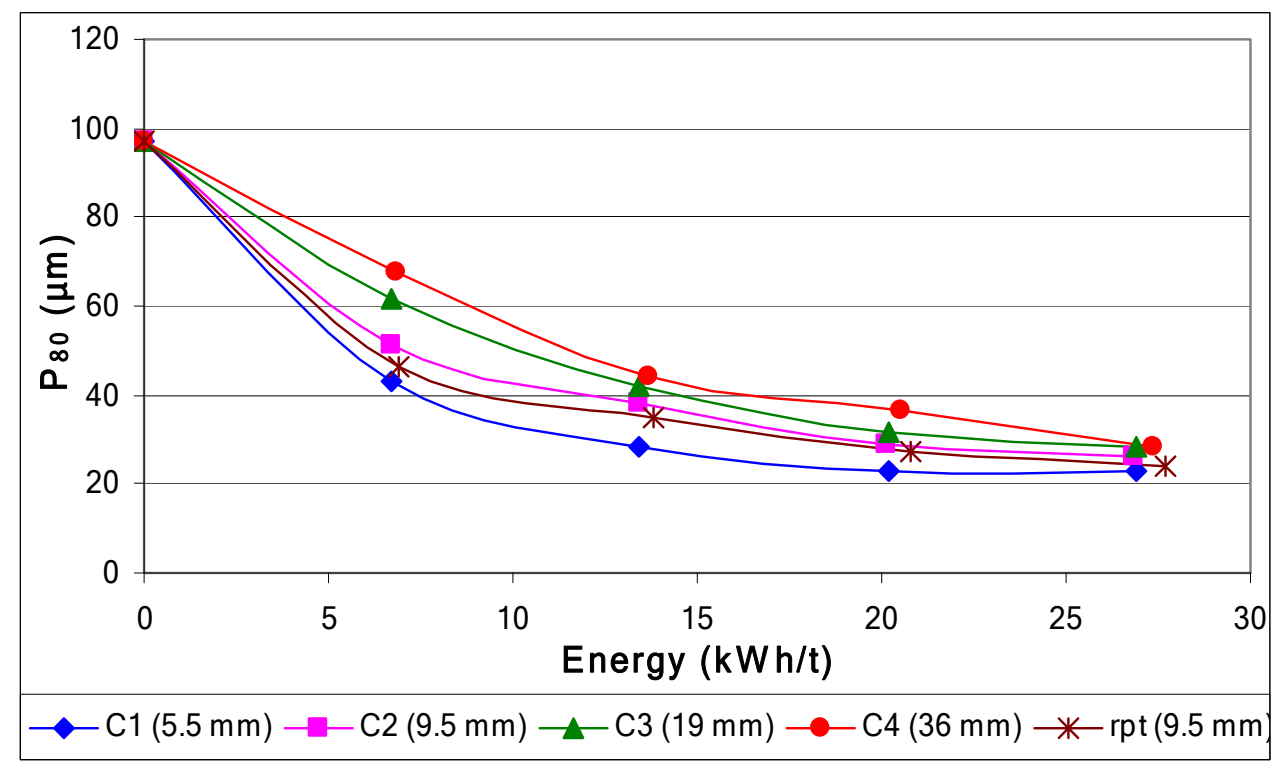

Fig. 2: $\mathrm{P}_{80}$ verses Energy for the $100 \mu \mathrm{m}$ feed (F2)

For this feed, the calculated best top ball size was $14 \mathrm{~mm}$. This is between Charges 2 and 3, however as with the previous tests using media smaller than this produced a more efficient grind.

\subsection{F3 $(500 \mu \mathrm{m})$ Feed Grinding Tests}

Shown in Figure 3 are the results on the first of the coarser feeds. Unlike the last two sets of results, not all charges are suitable for grinding the feed down to the fine size range. Only the two largest charges, represented by the green $(\boldsymbol{\Lambda})$ and red curves $(\mathbf{O})$, are capable of grinding the feed from $500 \mu \mathrm{m}$ to below $50 \mu \mathrm{m}$ in the time of the tests. The two smallest charges are unable to gain sufficient energy to break the large particles in the feed resulting in very little change in the $80 \%$ passing size. This makes these charges unsuitable for this size feed as it is unlikely that even at extended grind times, or higher energy inputs, a fine grind would be achieved. This supports the findings of Orumwense and Forssberg (1992), Gao and Weller (1994) and Alves and Lacoste-Bouchet (2005) who all found that smaller media are suited to fine feeds, while larger media are required for coarser feeds.

From the calculated top ball size for this charge, the best size media would have been between Charge 3 and 4. Once again a smaller charge produced the more efficient grind, even though in this case the difference between the grinds produced by the two charges is very small and hence either would be suitable to grind this size feed. 


\subsection{F4 $(1000 \mu \mathrm{m})$ Feed Grinding Tests}

In Figure 4, the results of the grinding tests on the $1000 \mu \mathrm{m}$ feed are shown. As with the last set of results the two smallest charges are not suitable for efficiently grinding this sized material. Charge 4 , the largest charge, is most suitable for grinding this feed to fine sizes.

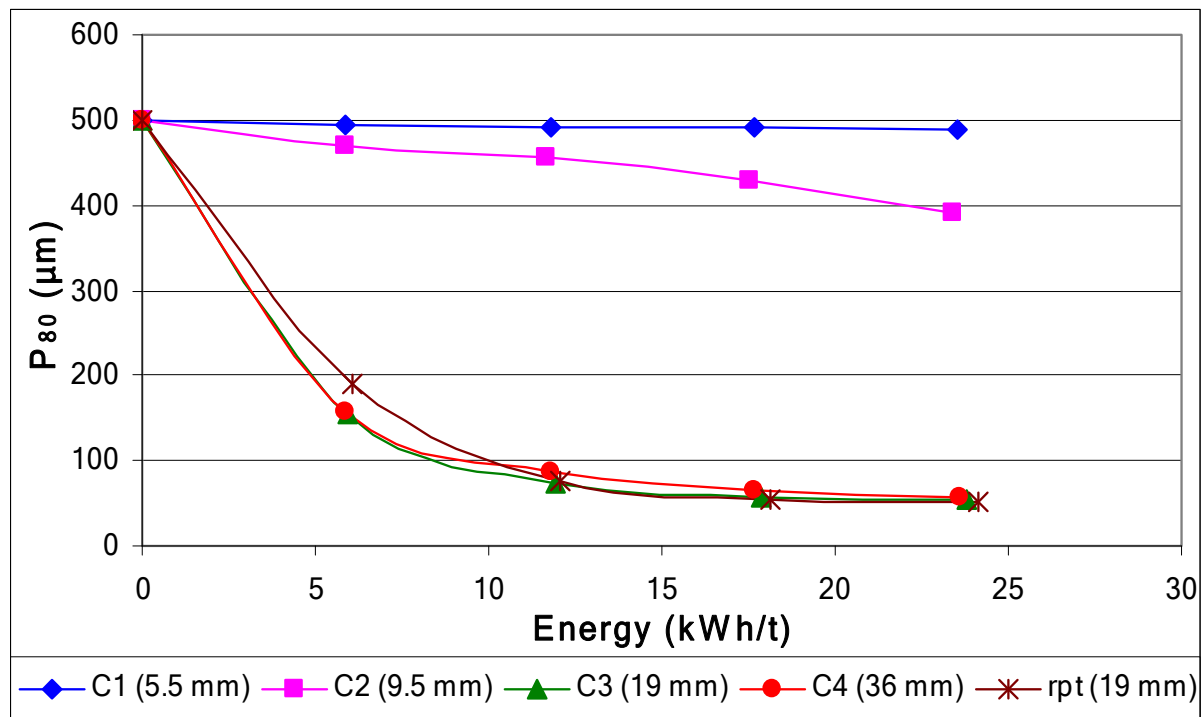

Fig. 3: $\mathrm{P}_{80}$ verses Energy for the $500 \mu \mathrm{m}$ feed (F3)

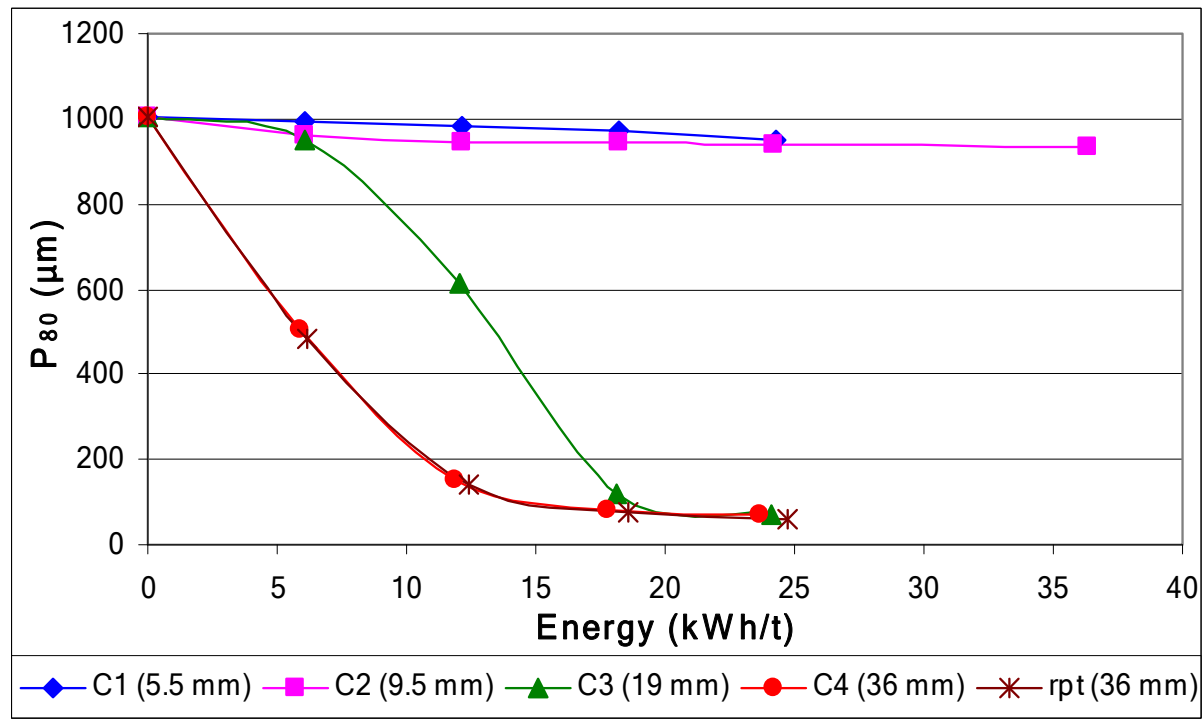

Fig. 4: $\mathrm{P}_{80}$ verses Energy for the $1000 \mu \mathrm{m}$ feed (F4)

Charge 3, represented in Figure 4 by the green curve $(\boldsymbol{\Delta})$, produced a curve not seen elsewhere in the results. It is likely that this charge is slightly too small to efficiently grind the material at low energy inputs or short grind times. Towards the end of the test however, the grind achievable was the same as that for the larger charge at the same energy consumption, indicating that Charge 3 requires a higher energy input to produce a fine grind. 
The estimated best top ball size for this $1000 \mu \mathrm{m}$ feed was $43 \mathrm{~mm}$, slightly larger than the largest charge. The largest charge still produced an efficient grind, following the trend of the other tests.

\subsection{The Optimum Top Ball Size}

From the grinding tests carried out on 55, 100, 500 and $1000 \mu \mathrm{m}$ feeds it has been found that the top ball size estimated by Equation 1 does not produce the most efficient grind. In all the tests it was found that a smaller top size ball charge produced a more efficient grind than the calculated top ball size media. This indicates that the formula derived by Bond for determining the best top ball size for a given feed is inaccurate in fine grinding situations and is only accurate down to a predicted ball size of approximately 38 $\mathrm{mm}$. Further investigation is needed to allow alterations of the formula to be made to make it valid for fine grinding applications.

\subsection{Observations on the $80 \%$ Passing Size}

As can be seen in Figures 3 and 4 the $80 \%$ passing size of the product from the tests carried out with Charges 1 and 2, the 5.5 and $9.5 \mathrm{~mm}$ top ball size charges respectively, did not change significantly over the grind time used. Figure 5 shows the size distributions for the $1000 \mu \mathrm{m}$ feed with Charge 2 after each five minutes of grinding. The grind time for this test was extended to half an hour to see if the $\mathrm{P}_{80}$ would decrease at longer grind times. As indicated where the line at $80 \%$ intersects the grind curves, there is very little change in the $\mathrm{P}_{80}$, even after 30 minutes.

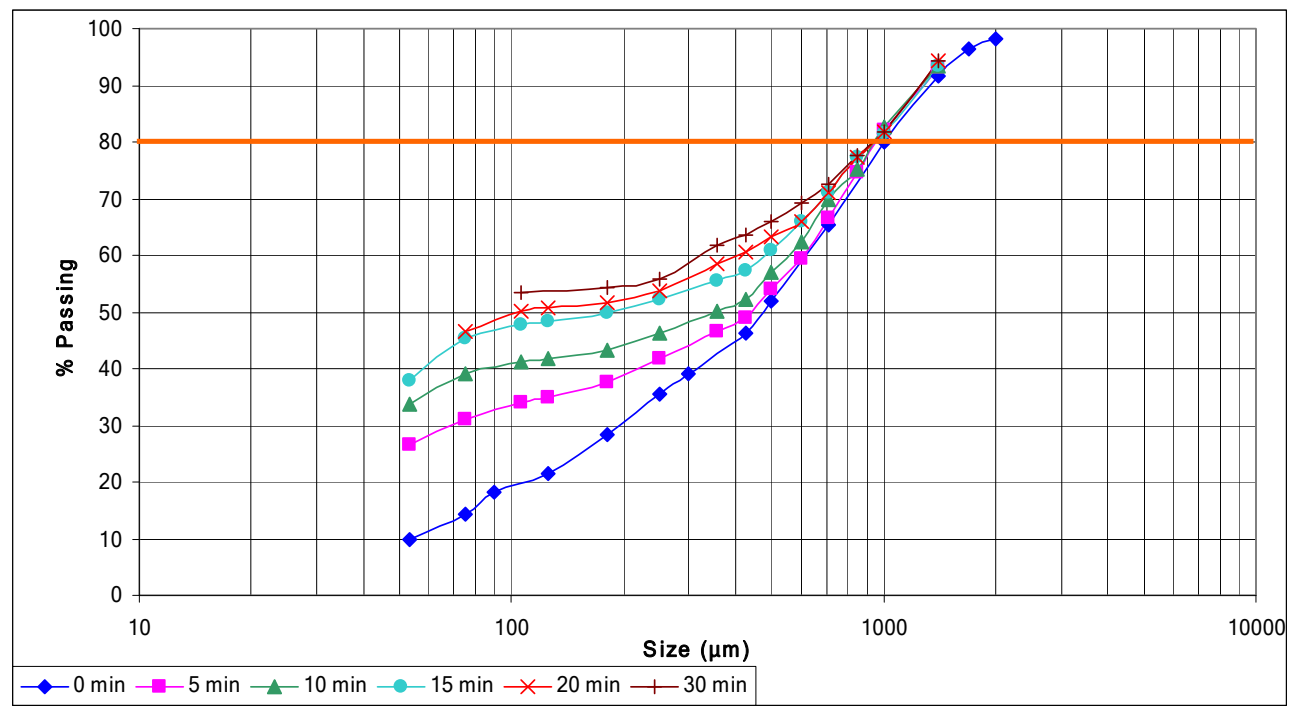

Fig. 5: Size distribution of the $1000 \mu \mathrm{m}$ feed ground with Charge 2

The shape of the distributions however, has changed over the duration of the grind. From Figure 5 it appears that very little grinding is occurring above approximately $800 \mu \mathrm{m}$, while the finer fractions are being ground. This supports the notion that small balls are not able to grind large particles by impact breakage, but are effective at generating fine particles (Austin et al., 1984). Similar trends in the size distributions were observed for each of the 500 and $1000 \mu \mathrm{m}$ feeds when ground with Charges 1 and 2 .

This may be a good method for determining the charge top size relating to feed size as it demonstrates the size above which little grinding occurs. Further investigation of different work index ores and a comparison of the grinding rate of the individual size fractions, would delineate the particle size at which grinding becomes inefficient with the ball size used. This would indicate the feed size above which the ball size should not be used if efficient grinding is desired. 


\subsection{Operating Work Index Analysis}

The operating work index for each five minutes of grinding for each test was determined using Equation 3:

$$
\mathrm{W}_{\mathrm{io}}=\frac{\text { Energy }}{10\left(\frac{1}{\sqrt{\mathrm{P}}}-\frac{1}{\sqrt{\mathrm{F}}}\right)}
$$

where:

$\mathrm{W}_{\mathrm{io}}=$ operating work index $(\mathrm{kWh} / \mathrm{t})$

$\mathrm{P}=80 \%$ passing size of product

$\mathrm{F}=80 \%$ passing size of feed.

Plots of the operating work index against the $\mathrm{P}_{80}$, such as Figure 6, confirm the trends identified by the grind-energy analysis. Figure 7 is for the $1000 \mu \mathrm{m}$ feed. This graph confirms the trend that using smaller media for the coarser feeds was ineffective, with the work index dramatically increasing for very little decrease in the grind size. This is demonstrated by the flatness of the Charge 1 and 2 curves.

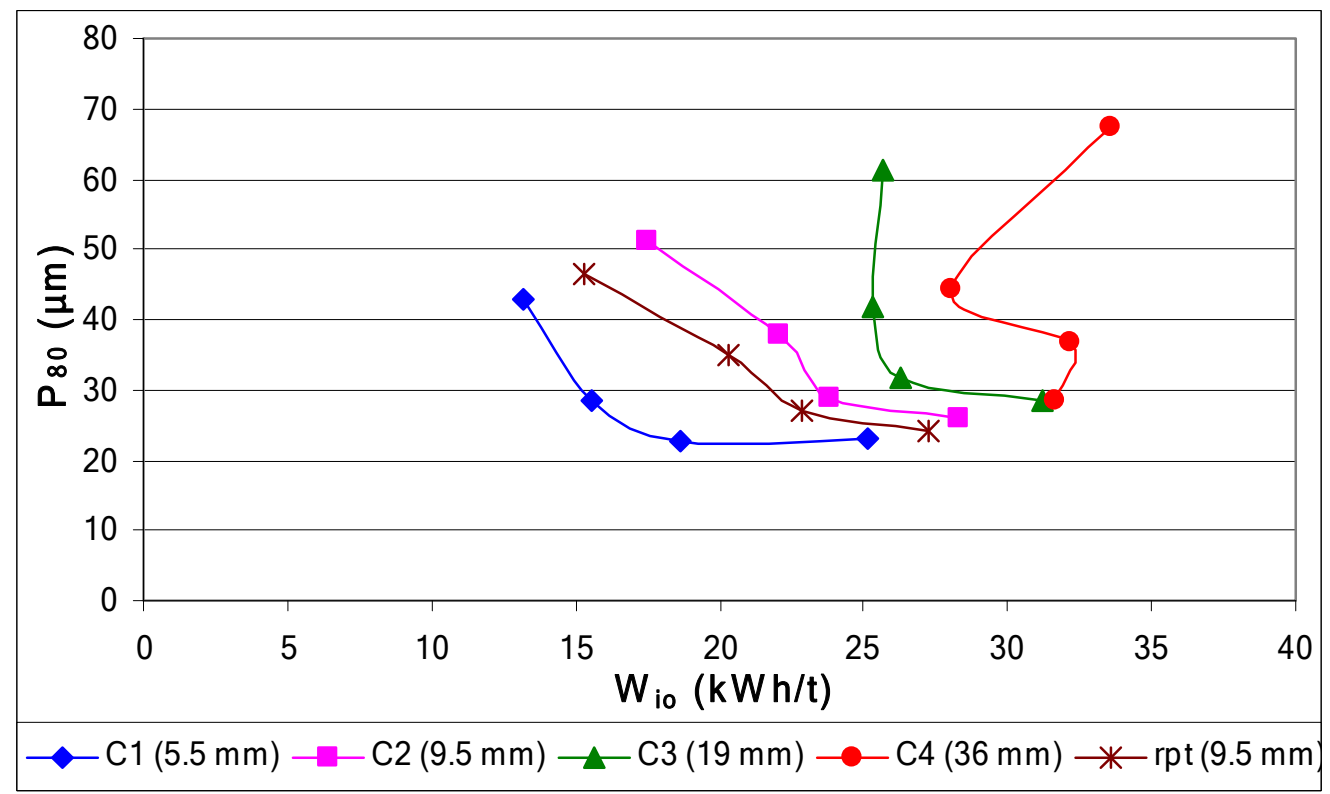

Fig. 6: Operating work index versus $\mathrm{P}_{80}$ for the $100 \mu \mathrm{m}$ feed

The operating work index analysis identified the change in efficiency which is thought to occur when grinding of individual crystal grain boundaries dominates over grinding of the matrix, typically between 20 and $30 \mu \mathrm{m}$. This can be seen in Figure 6 where there is a large increase in the operating work index below a $\mathrm{P}_{80}$ of $30 \mu \mathrm{m}$. This is also the point where minimal size reduction occurs for a large input in energy. At this point the cost of fine grinding increases dramatically as it is no longer the particle matrix being ground, but the individual grains. This trend however does not only occur in horizontal ball mills, but also in vertical mills as well. 


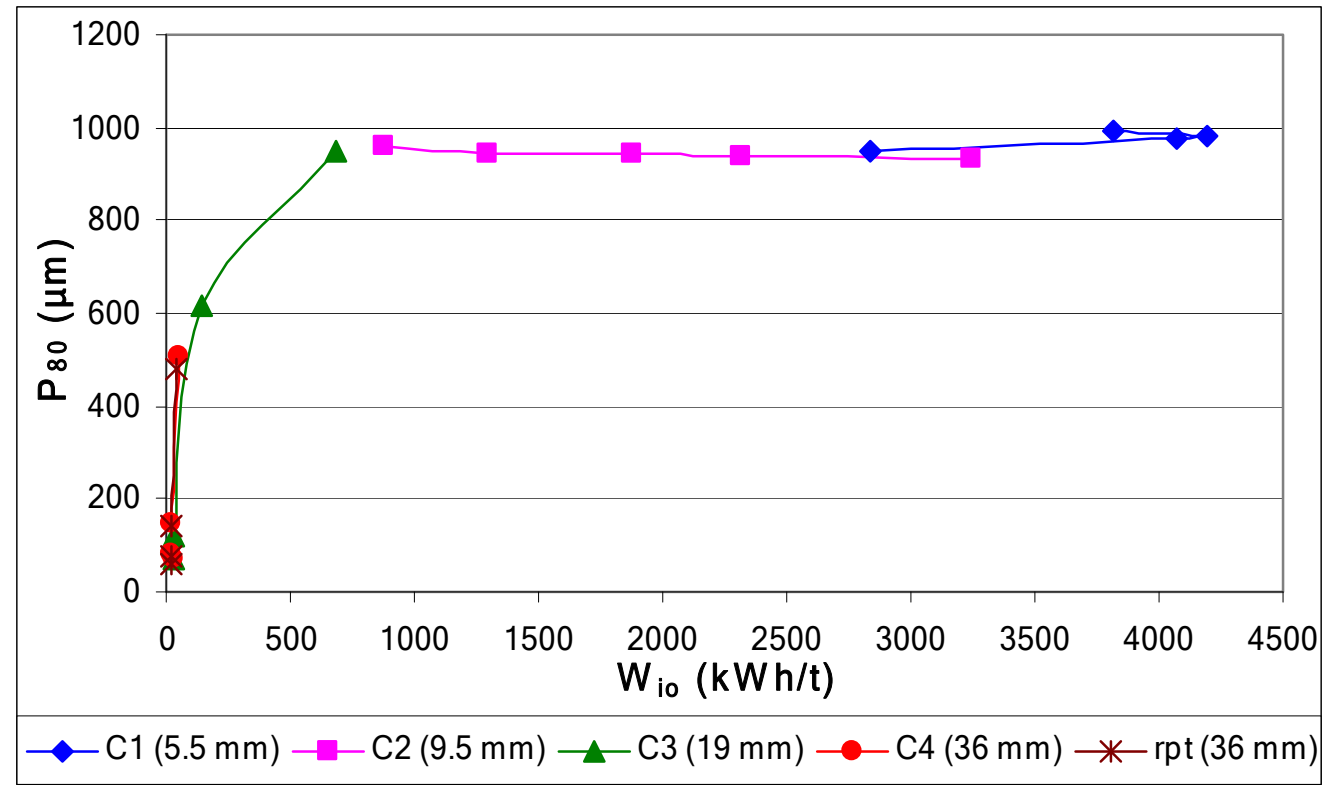

Fig.7: Operating work index versus $\mathrm{P}_{80}$ for the $1000 \mu \mathrm{m}$ feed

\section{Conclusions}

The grinding test work carried out for this investigation was aimed at identifying trends in the energy consumption in fine grinding situations. Analysis of the results from these grinding tests has identified the following:

- Efficient grind curves for fine grinding form the same shape as those for traditional ball mill grinding (exponential decay),

- Small balls are most suited for fine feeds, while larger balls are suited to coarse feeds,

- Small media is the most efficient at generating fine particles, but is inefficient and unsuitable for breaking large particles,

- The most efficient top size balls for fine grinding appeared to be smaller than those predicted by Bond's ball sizing formula,

- Operating work index analysis confirms the above results,

- Operating work index analysis identifying the change from grinding of the particle matrix to that of the crystal grain boundary at between 20 to $30 \mu \mathrm{m}$ for this ore, and

- The possibility of using the size distribution curves over the duration of the grind to predict the feed size at which a ball charge becomes ineffective and inefficient.

\section{Acknowledgements}

The authors would like to acknowledge the knowledge and finanacial support of Orway Mineral Consultants, Outokumpu, Newmont Australia, Donhad Australia Pty Ltd, and CBC Bearings Power Transmission, Kalgoorlie, for sourcing and providing small ball bearings as grinding media.

\section{References}

Alves, V.K. and Lacoste-Bouchet, P., Comparative Grinding Pilot Tests of Grinding Balls vs. Balls/Millpebs Blend, National Canadian Mineral Processor Conference 2005, Ottawa.

Austin, L.G., Klimpel, R.R. and Luckie, P.T., Process Engineering of Size Reduction: Ball Milling, SMEAIME, New York, 1984. 
Bond, F.C., Crushing and Grinding Calculations, Allis-Chalmers Manufacturing Company, reprinted from British Chemical Engineers, 1961.

Gao, M.W. and Weller, K.R. A Comparison of Tumbling Mills and Stirred Ball Mills for Wet Grinding, Fifth Mill Operators' Conference, Australian Institute of Mining and Metallurgy, Australia, 1994, pp. 61-67.

Jankovic, A. and Morrell, S. Scale-up of Tower Mill Performance using Modelling and Simulation, Proceedings of the XXI International Mineral Processing Congress, 2000.

Levin, J., A Proposed Test for the Determination of the Grindability of Fine Materials, Mintek Report M177, 1984, Council for Mineral Technology, South Africa.

Orumwense, O.A. and Forssberg, E. Superfine and Ultrafine Grinding - A Literature Survey, Mineral Processing and Extractive Metallurgy Review, 1992, vol. 11, pp. 107-127.

Pease, J.D., Young, M.F., Curry, D. and Johnson, N.W. Improving Fines Recovery by Grinding Finer, Metallurgical Plant Design and Operating Strategies Conference Proceedings, The Australasian Institute of Mining and Metallurgy, Perth, 2004, pp 65-78.

Reese, P. Innovations in Mineral Processing Technology, Proceedings of the New Zealand Minerals \& Mining Conference, 29031 October, 2000.

Wardell-Johnson, L. Private Communication, 2006.

Yan, D.S., Freeman, M. and Dunne, R. The Efficiency of Ultra-fine Grinding in Stirrer Mills, XIX Int. Min. Proc. Congress, San Francisco, October, 1995.

Zheng, J., Harris, C.C. and Somasundaran, P. Power Consumption of Stirred Media Mills, SME Annual Meeting, Albuquerque, New Mexico, Preprint No. 94-118, 1994. 